\title{
HUBUNGAN JAM KERJA, TATA RUANG KANTOR DAN PENGAWASAN DENGAN PRODUKTIVITAS KERJA PEGAWAI BADAN PEMBERDAYAAN MASYARAKAT (BPM) KABUPATEN SOLOK
}

\author{
Dessyta Gumanti \\ Dosen Program Studi Pendidikan Ekonomi STKIP- PGRI Sumbar \\ Jl. Gunung Pangilun No.1, Padang Sumatera Barat \\ Email: dessytasays@gmail.com
}

submitted: 2015.07.31 reviewed: 2015.11.06 accepted: 2016.06.23

http://dx.doi.org/10.22202/economica.2015.v4.i1.262

\begin{abstract}
Labor productivity is defined as the ability of a person or group of people to produce goods and services. The study was descriptive correlational. The population of the research that is the entire body of community empowerment officer Solok Regency as much as 38 employees. Sampling method used. total sampling.The data in this study comes from the primary data from the deployment of questionnaires and secondary data from the documentation and study of literature. Based on the results of data analysis that (1) There is a significant relationship between work hours, office layout and supervision together with the productivity of labor (2) There is a significant relationship between hours worked and productivity of work 3) There is a significant relationship between corporate office space with work productivity, and (4) There is a significant relationship between job control and productivity.
\end{abstract}

\begin{abstract}
Abstrak
Produktivitas kerja diartikan sebagai kemampuan seseorang atau kelompok orang untuk menghasilkan barang dan jasa. Jenis penelitian ini adalah deskriptif korelasional. Populasi penelitian yaitu seluruh pegawai Badan Pemberdayaan Masyarakat Kabupaten Solok sebanyak 38 orang pegawai. Metode pengambilan sampel yang digunakan yaitu total sampling. Data dalam penelitian ini berasal dari data primer yaitu dari penyebaran angket dan data sekunder yang berasal dari dokumentasi dan studi kepustakaan. Berdasarkan hasil analisis data diperoleh bahwa (1) bahwa (1) Terdapat hubungan yang berarti antara jam kerja, tata ruang kantor dan pengawasan secara bersama-sama dengan produktivitas kerja (2) Terdapat hubungan yang berarti antara jam kerja dengan produktivitas kerja (3) Terdapat hubungan yang berarti antara tata ruang kantor dengan produktivitas kerja Dan (4) Terdapat hubungan yang berarti antara pengawasan dengan produktivitas kerja.
\end{abstract}

Keywords : Hours Of Work, Spatial And Oversight Office Work Productivity With Employees 


\section{PENDAHULUAN}

Keberadaan sumber daya manusia di dalam suatu organisasi baik itu pemerintahan maupun swasta memegang peranan sangat penting. Sumber daya manusia merupakan penggerak segala aktivitas yang ada pada organisasi. Dalam suatu instansi pemerintah maupun swasta sangat diperlukan adanya produktivitas kerja untuk mencapai tujuan yang telah ditetapkan.

Produktivitas kerja merupakan suatu akibat dari persyaratan kerja yang harus dipenuhi oleh pegawai untuk memperoleh hasil maksimal, dimana dalam pelaksanaannya produktivitas kerja terletak pada faktor manusia sebagai pelaksana kegiatan pekerjaan. Jadi faktor manusia memegang peranan penting dalam mencapai hasil agar sesuai dengan tujuan instansi tersebut, karena betapapun sempurnanya peralatan kerja tanpa adanya tenaga manusia tidak akan berhasil memproduksi barang atau jasa sesuai dengan tujuan yang ingin dicapai ( Slamet, 2001:114).

Menurut Payaman (1998:38) produktivitas mengandung pengertian filosofis-kualitatif dan kuantitatif-teknis operasional. Secara filosofis-kualiatif, produktivitas mengandung pandangan hidup dan sikap mental yang selalu berusaha untuk meningkatkan mutu kehidupan. Keadaan hari ini lebih baik daripada kemarin, dan mutu kehidupan besok harus lebih baik daripada hari ini. Untuk defenisi kerja secara kuantitatif, produktivitas merupakan perbandingan antara hasil yang dicapai (keluaran) dengan keseluruhan sumber daya (masukan) yang digunakan persatuan waktu.

Dalam usaha pencapaian tujuan tersebut, maka perlu adanya peningkatan produktivitas kerja pegawai. Produktivitas kerja juga sering diartikan sebagai kemampuan seseorang atau kelompok orang untuk menghasilkan barang atau jasa. Tujuan utama dari peningkatan produktivitas kerja pegawai adalah agar pegawai baik ditingkat bawah maupun ditingkat atas mampu menjadi pegawai yang efisien, efektif dan produktif.
Seorang pegawai yang produktif adalah pegawai yang cekatan dan mampu menghasilkan barang atau jasa sesuai mutu yang ditetapkan dan waktu yang lebih singkat. Dengan demikian penting bagi seorang pimpinan berusaha untuk meningkatkan produktivitas kerja pegawai, agar instansi dapat berkembang dan dapat mempertahankan usahanya.

Dalam usaha untuk mencapai suatu produktivitas kerja yang optimal dari proses pekerjaan pegawai, dapat dipengaruhi oleh berbagai faktor. Faktorfaktor tersebut antara lain yaitu motivasi, pendidikan, disiplin kerja, keterampilan, sikap etika kerja, gizi dan kesehatan, tingkat penghasilan, lingkungan kerja dan iklim kerja, teknologi, sarana produksi, jaminan sosial, manajemen, dan kesempatan berprestasi (Pandji, 2004:178).

Henry (2004:362) menyatakan faktor-faktor yang digunakan dalam pengukuran produktivitas kerja meliputi kuantitas kerja; kualitas kerja; dan ketepatan waktu. Kuantitas kerja adalah merupakan suatu hasil yang dicapai oleh karyawan dalam jumlah tertentu dengan perbandingan standar yang ada atau ditetapkan oleh perusahaan. Kualitas kerja adalah merupakan suatu standar hasil yang berkaitan dengan mutu dari suatu produk yang dihasilkan oleh karyawan dalam hal ini merupakan suatu kemampuan karyawan dalam menyelesaikan pekerjaannya secara teknis dengan perbandingan standar yang ditetapkan oleh perusahaan dan ketepatan waktu merupakan tingkat suatu aktivitas diselesaikan pada awal waktu yang dinyatakan, dilihat dari sudut koordinasi dengan hasil output serta memaksimalkan waktu yang tersedia untuk aktivitas lain.

Pelaksanaan pekerjaan yang baik haruslah memperhatikan faktor-faktor yang sangat mempengaruhi produktivitas kerja dalam pencapaian tujuan organisasi. Salah satu faktor yang mempengaruhi produktivitas kerja dapat dilihat dari jam kerja pegawai. Muchdarsyah (2008:63) mengemukakan bahwa salah satu area potensial tertinggi dalam peningkatan produktivitas adalah mengurangi jam kerja yang tidak efektif. Jam kerja merupakan 
jumlah waktu yang digunakan secara efektif untuk menyelesaikan pekerjaan. Waktu kerja tersebut kebanyakan tidak dimanfaatkan secara optimal oleh pegawai.

Kantor Badan Pemberdayaan Masyarakat (BPM) merupakan salah satu instansi pemerintahan yang yang berada di lingkungan Pemerintah Daerah Kabupaten Solok yang memberikan pelayanan bagi pemberdayaan masyarakat seperti pemberian kredit lunak bagi masyarakat yang melakukan usaha. Untuk itu sangat diperlukan sumber daya manusia yang berkualitas untuk mewujudkan peran tersebut.

Dalam observasi awal yang telah penulis lakukan terlihat produktivitas kerja pegawai masih kurang optimal. Hal ini terlihat dari masih adanya beberapa pegawai yang mangkir dari jam kerja. Berikut data pegawai yang tanpa keterangan, terlambat dan cepat pulang di kantor Badan Pemberdayaan Masyarakat

Tabel 1. Data Absensi Pegawai Tanpa Keterangan (TK), Terlambat Datang (TD) dan Cepat Pulang (CP) Badan Pemberdayaan Masyarakat Bulan Januari Desember 2014

\begin{tabular}{|c|c|c|c|c|c|c|c|c|c|c|}
\hline \multirow{2}{*}{ Bulan } & \multirow{2}{*}{$\begin{array}{l}\text { Jumlah } \\
\text { Pegawai }\end{array}$} & \multirow{2}{*}{$\begin{array}{c}\text { Hari } \\
\text { Kerja }\end{array}$} & \multirow{2}{*}{$\begin{array}{c}\text { Hari } \\
\text { Kerja } \\
\text { Pegawai }\end{array}$} & \multirow{2}{*}{$\begin{array}{c}\text { Jam } \\
\text { Kerja } \\
\text { Pegawai/ } \\
\text { Bulan }\end{array}$} & \multicolumn{3}{|c|}{ Jumlah Absensi } & \multicolumn{3}{|c|}{ Tingkat Absensi } \\
\hline & & & & & (TK) & (TD) & (CP) & (TK) & (TD) & (CP) \\
\hline Januari & 38 & 21 & 798 & 6384 & 6 & 5 & 39 & 0.75 & 0.07 & 0.61 \\
\hline Februari & 38 & 18 & 684 & 5472 & 3 & 1 & 1 & 0.29 & 0.01 & 0.01 \\
\hline Maret & 38 & 23 & 874 & 6992 & 4 & 3 & 13 & 0.45 & 0.04 & 0.18 \\
\hline April & 38 & 20 & 760 & 6080 & 1 & 4 & 7 & 0.13 & 0.06 & 0.11 \\
\hline Mei & 38 & 21 & 798 & 6384 & 6 & 6 & 3 & 0.75 & 0.09 & 0.04 \\
\hline Juni & 38 & 20 & 760 & 6080 & 9 & 5 & 3 & 0.18 & 0.08 & 0.04 \\
\hline Juli & 38 & 21 & 798 & 6384 & 6 & 6 & 4 & 0.75 & 0.09 & 0.06 \\
\hline Agustus & 38 & 20 & 760 & 6080 & 4 & 4 & 3 & 0.52 & 0.06 & 0.04 \\
\hline September & 38 & 22 & 836 & 6688 & 6 & 4 & 4 & 0.71 & 0.05 & 0.05 \\
\hline Oktober & 38 & 21 & 798 & 6384 & 4 & 5 & 1 & 0.50 & 0.07 & 0.01 \\
\hline November & 38 & 22 & 836 & 6688 & 20 & 5 & 3 & 2.39 & 0.07 & 0.04 \\
\hline Desember & 38 & 22 & 836 & 6688 & 8 & 2 & 3 & 0.95 & 0.04 & 0.04 \\
\hline
\end{tabular}

Sumber : Badan Pemberdayaan Masyarakat (BPM)

Keterangan : $\quad$ TiTING

Jumlah Pegawai

: Jumlah

keseluruhan Pegawai

Hari Kerja

: Jumlah hari

kerja yang efektif

Hari Kerja Pegawai Tingkat Jumlah pegawai X hari kerja

Jam Kerja Pegawai/bulan : Jam

kerja/hari $\mathrm{X}$ hari kerja seluruh pegawai

Jumlah absensi TK

Tanpa

Keterangan

Jumlah absensi TD

Datang

Jumlah absensi CP $\quad$ : $\quad$ Cepat

Pulang
Tingkat absensi TK : Jumlah pegawai (TK) : hari kerja pegawai x $100 \%$

Tingkat absensi TD : Jumlah pegawai (TD) : jam kerja pegawai/bulan $\mathrm{x}$ $100 \%$

Absensi CP : Jumlah pegawai $(\mathrm{CP})$ : jam kerja pegawai/bulan $\mathrm{x}$ $100 \%$

Berdasarkan tabel 1 terlihat tingkat absensi pegawai mengalami pasang surut atau fluktuatif. Dimana jam kerja belum dimanfaatkan secara optimal dan belum mendapat perhatian khusus dari pimpinan terhadap pegawai yang mangkir dari jam kerja efektif. Berkurangnya jumlah pegawai pada jam-jam kerja efektif 
tentunya akan berdampak kepada penurunan produktivitas kerja.

Berdasarkan observasi yang penulis lakukan, penulis menemukan beberapa indikasi yang mengungkapkan gejalagejala penurunan produktivitas kerja pegawai seperti kurangnya minat menyelesaikan kerja tepat waktu, sehingga banyak jam kerja yang terbuang karena terbengkalainya pekerjaan. Ketika tugas diberikan oleh pimpinan masih banyak pegawai yang masih menunda-nunda pekerjaan, menelpon keluarga atau izin keluar kantor untuk urusan-urusan yang tidak berkaitan dengan tugas pekerjaannya. Apabila hal ini terus berlanjut tentunya akan berdampak terhadap pencapaian tujuan organisasi, untuk itu perlu diperhatikan beberapa faktor yang mempengaruhi produktivitas kerja tersebut.

Faktor lain yang memberikan pengaruh terhadap produktivitas kerja dapat dilihat dari faktor lingkungan kerja, dalam hal ini adalah tata ruang kantor. Badri (2000:189) mengemukakan bahwa produktivitas suatu organisasi baik langsung ataupun tidak langsung akan dipengaruhi oleh penataan ruang kerja (layout). Dalam bekerja, tata ruang berperan penting dalam menunjang pekerjaan. Ruangan kantor yang tersusun dengan baik dan rapi cenderung membuat pegawai merasa betah dan nyaman dalam bekerja sehingga pekerjaan dapat diselesaikan dengan baik.

The Liang (2000:186) menjelaskan bahwa tata ruang kantor adalah penentuan mengenai kebutuhan-kebutuhan ruang dan tentang penggunaan secara terperinci dari ruangan ini untuk menyiapkan suatu susunan yang praktis dari yang faktorfaktor fisik yang dianggap perlu bagi pelaksanaan kerja. Ruang kantor yang kurang tertata dengan baik juga diindikasi menyebabkan produktivitas belum efektif. Tata ruang kantor merupakan penyusunan perabotan dan alat perlengkapan pada luas lantai yang tersedia. Berdasarkan observasi yang penulis lakukan, terlihat penataan ruang kantor masih kurang diperhatikan seperti komposisi jumlah pegawai dengan luas ruangan. Hal ini dapat dilihat dari tabel 2 berikut:

Tabel 2. Data Jumlah Pegawai dan Luas Ruangan Kantor Badan Pemberdayaan Masyarakat kabupaten Solok.

\begin{tabular}{|c|c|c|c|}
\hline No. & Bidang & $\begin{array}{l}\text { Jumlah } \\
\text { Pegawai }\end{array}$ & Luas Ruangan \\
\hline 1. & Sekretariat & 13 orang & $6 \times 6 \mathrm{~m}^{2}$ \\
\hline 2. & $\begin{array}{l}\text { Bidang penguatan kelembagaan dan } \\
\text { pengembangan partisipasi }\end{array}$ & 8 orang & $5 \times 6 \mathrm{~m}^{2}$ \\
\hline 3. & $\begin{array}{l}\text { Bidang pemberdayaan usaha ekonomi } \\
\text { masyarakat }\end{array}$ & 9 orang & $5 \times 6 \mathrm{~m}^{2}$ \\
\hline 4. & $\begin{array}{l}\text { Bidang pemberdayaan pemanfaatan } \\
\text { teknologi tepat guna dan sumber daya } \\
\text { nagari }\end{array}$ & 8 orang & $5 \times 6 \mathrm{~m}^{2}$ \\
\hline & Jumlah & orang & \\
\hline
\end{tabular}

Sumber: Kantor Badan Pemberdayaan Masyarakat (BPM)

Berdasarkan tabel 2 terlihat perbandingan komposisi pegawai kurang seimbang dengan luas ruangan yang tersedia, seperti ruangan untuk sekretariat dengan ketiga bidang lainnya. Terlihat hanya sedikit perbedaan luas ruangan antara ruangan yang mempunyai pegawai 13 orang dengan
8 orang pegawai. Ruang sekretariat yang cukup luas dengan jumlah pegawai yang banyak juga ditempatkan berbagai macam perabotan sehingga terkesan sempit dan sesak. Pada bidang Pemberdayaan Usaha Ekonomi Masyarakat, terlihat dokumendokumen yang tidak disusun rapi dan 
ditumpuk dalam karung masih diletakkan di ruangan kerja sehingga menyebabkan pemandangan yang tidak nyaman.

Lingkungan fisik yang tidak begitu mendukung seperti pencahayaan, suara dan warna ruangan. Pekerjaan pegawai yang bersifat operasional atau monoton membutuhkan sentuhan warna cerah untuk meningkatkan semangat kerja yang juga akan berdampak terhadap produktivitas kerja.

Produktivitas kerja pegawai juga dapat dipengaruhi oleh faktor pengawasan. Pengawasan perlu dilakukan untuk hasil pekerjaan yang baik dan bermutu tinggi. Pada setiap instansi pemerintah maupun swasta memerlukan pengawasan dari pihak manajer. Pengawasan ini dilakukan oleh pimpinan sebagai suatu usaha membandingkan apakah yang dilakukan sesuai dengan rencana yang ditetapkan. Dengan pengawasan yang baik akan mendorong pegawai lebih giat dalam bekerja dan menghasilkan kerja yang baik pula serta produktivitas kerja yang meningkat.

Mockler dalam Hani (2000:360) menyatakan bahwa pengawasan manajemen adalah suatu usaha sistematik untuk menetapkan standar dalam pelaksanaan dengan tujuan-tujuan perencanaan, merancang sistem informasi umpan balik, membandingkan kegiatan nyata dengan standar yang ditetapkan sebelumnya, menentukan dan mengukur penyimpangan-penyimpangan, serta mengambil tindakan koreksi yang diperlukan untuk menjamin bahwa semua sumber daya perusahaan dipergunakan dengan cara paling efektif dan efisien dalam pencapaian tujuan-tujuan perusahaan.

Untuk melaksanakan kegiatan pengawasan harus melalui tahapan-tahapan sebagai bentuk dari proses kegiatan pengawasan. Menurut Hani (2000:362) proses pengawasan biasanya terdiri paling sedikit lima tahap. Tahap-tahapnya adalah (1) penetapan standar pelaksanaan (perencanaan), (2) penentuan pengukuran pelaksanaan kegiatan, (3) pengukuran pelaksanaan kegiatan nyata, pembandingan pelaksanaan kegiatan dengan standar dan penganalisaan penyimpangan-penyimpangan, dan (5) pengambilan tindakan koreksi bila perlu.

Berdasarkan observasi yang penulis lakukan kegiatan pengawasan di kantor Badan Pemberdayaan Masyarakat Kabupaten Solok belum terlaksana sesuai dengan hasil yang diharapkan. Dimana pengawasan biasanya dilakukan secara formal dan secara situasional. Secara formal atau periodik kegiatan pengawasan dilakukan dengan rapat berkala minimal satu kali sebulan dan secara situasional berupa pengawasan harian. Namun kenyataannya hal tersebut kurang terlaksana, dimana kegiatan rapat berkala tidak berlangsung tiap bulannya dan pimpinan juga jarang mengawasi kegiatan harian pegawai. Hal ini disebabkan karena kurangnya perhatian dari pimpinan untuk mengontrol kegiatan pegawai dan pimpinan yang sering tidak berada ditempat sehingga pegawai merasa tidak diawasi dalam bekerja, sehingga pekerjaan tidak terlaksana dengan baik sesuai dengan sasaran yang diharapkan.

Melihat kenyataan yang dihadapi tersebut, diduga ada hubungan antara jam kerja, tata ruang kantor dan pengawasan dengan produktivitas kerja pegawai. Oleh karena itu penulis tertarik untuk melakukan suatu penelitian tentang "Hubungan Jam kerja, Tata Ruang Kantor dan Pengawasan dengan Produktivitas Kerja Pegawai Badan Pemberdayaan Masyarakat Kabupaten Solok'.

\section{KAJIAN TEORI}

\section{METODE PENELITIAN}

Jenis penelitian yang akan dilakukan adalah deskriptif korelasional. Populasi dalam penelitian ini adalah seluruh pegawai kantor Badan Pemberdayaan Masyarakat Kabupaten Solok yaitu 38 orang. Teknik pengambilan sampel pada penelitian ini adalah Total Sampling karena populasinya $<100$.

Jenis dan sumber data dalam penelitian ini menggunakan data primer dan data sekunder. Teknik pengumpulan 
data dalam penelitian ini dilakukan melalui kuesioner dan dokumentasi. Instrumen penelitian ini adalah menggunakan kuesioner dengan skala likert. Sebelum kuesioner digunakan, terlebih dahulu dilakukan uji validitas dan uji reabilitas. Analisis data menggunakan analisis korelasi untuk mengetahui hubungan masing-masing variabel bebas dengan variabel terikat.

\section{HASIL PENELITIAN DAN \\ PEMBAHASAN}

Tabel 4 Korelasi

\begin{tabular}{|c|c|c|c|c|c|}
\hline & & jam kerja & $\begin{array}{l}\text { tata ruang } \\
\text { kantor }\end{array}$ & pengawasan & $\begin{array}{c}\text { produktivitas } \\
\text { kerja }\end{array}$ \\
\hline \multirow[t]{3}{*}{ jam kerja } & Pearson Correlation & 1 & $.616^{\pi \times}$ & $.604^{\pi x}$ & $.597^{\pi x}$ \\
\hline & Sig. (2-tailed) & & .000 & .000 & .000 \\
\hline & $\mathrm{N}$ & 38 & 38 & 38 & 38 \\
\hline \multirow[t]{3}{*}{ tata ruang kantor } & Pearson Correlation & $.616^{\star \star}$ & 1 & $.829^{* *}$ & $.673^{\star \star}$ \\
\hline & Sig. (2-tailed) & .000 & & .000 & .000 \\
\hline & $\mathrm{N}$ & 38 & 38 & 38 & 38 \\
\hline \multirow[t]{3}{*}{ pengawasan } & Pearson Correlation & $.604^{\pi x}$ & $.829^{\pi x}$ & 1 & $.682^{\pi x}$ \\
\hline & Sig. (2-tailed) & .000 & .000 & & .000 \\
\hline & $\mathrm{N}$ & 38 & 38 & 38 & 38 \\
\hline \multirow[t]{3}{*}{ produktivitas kerja } & Pearson Correlation & $.597^{\text {*x }}$ & $.673^{\text {*x }}$ & $.682^{* x}$ & 1 \\
\hline & Sig. (2-tailed) & .000 & .000 & .000 & \\
\hline & $\overline{\mathrm{N}}$ & 38 & 38 & 38 & 38 \\
\hline
\end{tabular}

Dari hasil perhitungan berdasarkan Tabel 35 menunjukkan bahwa terdapat hubungan antara jam kerja $\left(\mathrm{X}_{1}\right)$ dengan produktivitas kerja (Y) sebesar 0,597 dengan arah hubungan yang positif (tidak ada tanda negatif pada angka 0,597) dan tingkat keeratan sedang. Artinya semakin optimal pemanfaatan jam kerja semakin meningkat pula produktivitas kerja pegawai dan sebaliknya produktivitas akan menurun jika jam kerja tidak digunakan dengan efektif. Hubungan antara jam kerja $\left(\mathrm{X}_{1}\right)$ dan tata ruang kantor $\left(\mathrm{X}_{2}\right)$ sebesar
Sebelum menggunakan analisis korelasi dilakukan uji prasyarat yaitu uji normalitas, uji multikolineritas. Dari uji normalitas diperoleh hasil bahwa data terdistribusi normal. Kemudian dari uji multikolineritas diperoleh hasil bahwa seluruh variabel tidak memiliki masalah multikolineritas. Dari hasil uji tersebut memenuhi syarat untuk menggunakan analisis korelasi. Hasil analisis korelasi dapat dilihat pada tabel dibawah ini : 
Tabel 5. Kofisien Korelasi Berganda

\begin{tabular}{lrrrr}
\hline Model & $\mathrm{R}$ & \multicolumn{2}{c}{$\mathrm{R}$} & \multicolumn{2}{c}{$\begin{array}{c}\text { Adjusted } \mathrm{R} \\
\text { Square }\end{array}$} & $\begin{array}{c}\text { Std. Error of } \\
\text { the Estimate }\end{array}$ \\
\hline 1 & $733^{\mathrm{a}}$ & .538 & .497 & 9.899 \\
\hline
\end{tabular}

a. Predictors: (Constant), pengawasan, jam kerja, tata ruang kantor

\section{Sumber: Pengolahan Data Primer 2014}

Berdasarkan tabel diatas terlihat hubungan yang kuat dan positif antara jam kerja, tata ruang kantor dan pengawasan dengan produktivitas kerja sebesar 0,497

\section{Pembahasan}

Pembahasan hasil penelitian dilakukan berdasarkan hasil analisis deskriptif dan analisis induktif serta analisis hasil penelitian tentang hubungan jam kerja $\left(\mathrm{X}_{1}\right)$, tata ruang kantor $\left(\mathrm{X}_{2}\right)$ dan pengawasan $\left(\mathrm{X}_{3}\right)$ dengan produktivitas kerja $(\mathrm{Y})$ pegawai Badan Pemberdayaan Masyarakat Kabupaten Solok.

1) Hubungan jam kerja, tata ruang kantor dan pengawasan dengan produktivitas kerja pegawai Badan Pemberdayaan Masyarakat Kabupaten Solok.

Berdasarkan pengolahan data didapat bahwa jam kerja, tata ruang kantor dan pengawasan mempunyai hubungan yang berarti dengan produktivitas kerja pegawai Badan Pemberdayaan Masyarakat Kabupaten Solok. Berdasarkan hasil penelitian diperoleh nilai koefisien determinasi (Adjusted R Square) sebesar 0,497. Hal ini berarti kontribusi jam kerja, tata ruang kantor dan pengawasan dengan produktivitas kerja sebesar $49,7 \%$.

Sedangkan dari perhitungan uji F diperoleh $F_{\text {hitung }} 13,769$ dan $F_{\text {tabel }}$ sebesar 2,88 dan juga diketahui $r$ hitung sebesar 0,733 dengan $r$ tabel sebesar 0,320. Dengan demikian $F_{\text {hitung }}$ $\geq \mathrm{F}_{\text {tabel }}$ dan $\mathrm{r}$ hitung $\geq \mathrm{r}$ tabel maka Ho ditolak dan Ha diterima. Hal ini berarti bahwa terdapat hubungan yang berarti antara jam kerja, tata ruang kantor dan pengawasan dengan produktivitas kerja pegawai Badan Pemberdayaan
Masyarakat Kabupaten Solok. Dimana semakin baik cara jam kerja, tata ruang kantor dan pengawasan maka produktivitas kerja yang akan diperoleh juga akan meningkat dan sebaliknya.

Hasil penelitian ini sejalan dengan pendapat Muchdarsyah (2008:2) yang menyatakan bahwa pemanfaatan waktu kerja merupakan upaya paling dasar dari produktivitas kerja. Selain itu, tata ruang kantor akan mempengaruhi situasi dan suasana pegawai dalam bekerja. Ruangan kerja yang teratur dan tersusun dengan baik akan membuat pegawai merasa nyaman dan betah dalam bekerja. Selanjutnya untuk meningkatkan produktivitas kerja dibutuhkan pengawasan untuk mendorong pegawai agar lebih baik dalam bekerja berupa proses pengawasan yang dilakukan oleh pimpinan yang dimulai dari proses Penetapan standar pelaksanaan, penentuan pengukuran pelaksanaan kegiatan pelaksanaan kegiatan, pengukuran pelaksanaan kegiatan, kegiatan evaluasi atau pembandingan pelaksanaan nyata dengan standar yang ditetapkan pekerjaan pegawai dan tindakan pengambilan tindakan koreksi jika diperlukan jika diperlukan.

2) Hubungan jam kerja dengan produktivitas kerja pegawai Badan Pemberdayaan Masyarakat Kabupaten Solok.

Hasil penelitian menunjukkan bahwa adanya hubungan yang berarti antara jam kerja dengan produktivitas kerja pegawai Badan Pemberdayaan Masyarakat Kabupaten Solok dengan 
koefisien korelasi sebesar 0,597. Berdasarkan perhitungan diperoleh $\mathrm{t}_{\text {hitung }} 5,092$ dan $\mathrm{t}_{\text {tabel }}$ sebesar 2,038 dimana $t_{\text {hitung }} \geq t_{\text {tabel }}(5,092 \geq 2,038)$ atau $r$ hitung sebesar 0,673 dengan $r$ tabel sebesar 0,320 dimana $r$ hitung $\geq r$ tabel $(0,673 \geq 0,320)$ maka mengakibatkan hipotesis diterima.

Dari hasil penelitian yang dilakukan terbukti bahwa jam kerja berhubungan secara signifikan dengan produktivitas kerja pegawai Badan Pemberdayaan Masyarakat Kabupaten Solok. Hal ini berarti jika jam kerja dimanfaatkan dengan baik maka akan dapat meningkatkan produktivitas kerja pegawai. Dan sebaliknya jika jam kerja kurang dimanfaatkan dengan baik maka produktivitas kerja akan menurun. Hasil ini sesuai dengan pendapat Muchdarsyah (2008:63) yang menyatakan salah satu area potensial tertinggi dalam peningkatan produktivitas adalah mengurangi jam kerja yang tidak efektif.

Faustino (2003:172) menyatakan bahwa Bila pekerja dibayar pada waktu tidak bekerja maka hal negatif ini sungguh berpengaruh terhadap produktivitas. Waktu absen yang terlampau banyak tidak saja memakan banyak biaya tetapi juga berpengaruh negatif terhadap produktivitas jika orang-orang yang tidak terlatih menggantikan mereka yang berpengalaman, waktu menunggu yang terlampau lama bisa mencetuskan keluhan, pelayanan yang rendah kualitasnya bisa menimbulkan kebutuhan akan tambahan waktu staff untuk membereskan masalah.

Masih adanya pegawai yang tidak ada ditempat ketika jam kerja akan menimbulkan dampak berkurangnya jumlah pegawai yang ada di dalam kantor dan penyelesaian pekerjaan menjadi tertunda sehingga pelayanan menjadi menurun. Jika hal ini terus berlanjut tentunya akan mengakibatkan produktivitas kerja menurun karena sumber daya yang ada untuk melaksanakan pekerjaan juga berkurang.

3) Hubungan tata ruang kantor dengan produktivitas kerja pegawai Badan
Pemberdayaan Masyarakat Kabupaten Solok

Berdasarkan analisis data dan pengujian hipotesis yang telah dilakukan, hasil penelitian ini menunjukan adanya hubungan yang berarti antara tata ruang kantor dengan produktivitas kerja pegawai Badan Pemberdayaan Masyarakat Kabupaten Solok dengan koefisien korelasi yang diperoleh sebesar 0,673. Berdasarkan perhitungan diperoleh $\mathrm{r}$ hitung sebesar 0,673 dengan $r$ tabel sebesar 0,320 dimana $r$ hitung $\geq r$ tabel $(0,673 \geq$ 0,320 ) atau $t_{\text {hitung }}$ diperoleh 5,092 dan $\mathrm{t}_{\text {tabel }}$ sebesar 2,038 dimana $\mathrm{t}_{\text {hitung }} \geq \mathrm{t}_{\text {tabel }}$ $(5,092 \geq 2,038)$ akibatnya Ho ditolak dan Ha diterima.

Dari penelitian yang dilakukan terbukti bahwa tata ruang kantor berhubungan secara signifikan dengan produktivitas kerja pegawai Badan Pemberdayaan Masyarakat Kabupaten Solok. Hasil ini sesuai dengan pendapat MC Maryati (2008:148) mengatakan bahwa semakin baik tata ruang kantor, semakin memberikan rasa aman dan nyaman dalam bekerja serta meningkatkan produktivitas kerja.

Kondisi kantor yang tidak beraturan tentunya akan membuat pegawai merasa tidak nyaman dalam bekerja, oleh karena itu sangat penting untuk menciptakan kondisi kerja yang dapat mendukung pekerjaan itu sendiri. Faustino (2003:168) menyatakan bahwa kondisi kerja yang tidak nyaman jelas akan mengurangi kesempatan bagi pekerja untuk bekerja secara lebih efektif dan efisien.

Tata ruang yang baik akan membangun suasana yang aman dan nyaman di kantor serta akan mendorong pegawai untuk lebih giat bekerja. MC Maryati (2008:134) mengungkapkan bahwa lingkungan kerja yang baik akan membuat para pekerja nyaman. Jika para pekerja atau karyawan merasa nyaman dalam bekerja bisa dipastikan produktivitas akan meningkat. 
4) Hubungan pengawasan dengan produktivitas kerja pegawai Badan Pemberdayaan Masyarakat Kabupaten Solok

Berdasarkan hasil penelitian menunjukan bahwa adanya hubungan yang berarti antara pengawasan dengan produktivitas kerja pegawai Badan Pemberdayaan Masyarakat Kabupaten Solok dengan koefisien korelasi yang diperoleh yaitu 0,682. Berdasarkan perhitungan diperoleh $r$ hitung sebesar 0,682 dengan $r$ tabel sebesar 0,320 dimana $\mathrm{r}$ hitung $\geq \mathrm{r}$ tabel $(0,682 \geq$ $0,320)$ atau $t_{\text {hitung diperoleh } 5,597 \text { dan }}$ $t_{\text {tabel }}$ sebesar 2,038 dimana $t_{\text {hitung }} \geq t_{\text {tabel }}$ $(5,597 \geq 2,038)$ akibatnya Ho ditolak dan Ha diterima.

Dari hasil penelitian yang dilakukan terbukti bahwa pengawasan berhubungan secara signifikan dengan produktivitas kerja pegawai Badan Pemberdayaan Masyarakat Kabupaten Solok. Hasil ini sesuai dengan pendapat Sondang (2002:73) bahwa pengawasan merupakan alat yang ampuh untuk meningkatkan produktivitas kerja. Dengan pengawasan yang baik mampu membantu pegawai dalam meningkatkan produktivitas kerja dan membantu organisasi untuk mencapai tujuan yang diharapkan. Hal ini didukung oleh proses pengawasan yang berlangsung dengan baik yang dimulai dari penetapan standar pelaksanaan, penentuan pengukuran pelaksanaan kegiatan pelaksanaan kegiatan, pengukuran pelaksanaan kegiatan, evaluasi atau pembandingan pelaksanaan nyata dengan standar yang ditetapkan dan pengambilan tindakan koreksi jika diperlukan. Muchdarsyah

(2008:72)

menyatakan bahwa kunci bagi produktivitas adalah menyusun pengawasan yang baik agar terdapat keseimbangan alokasi pekerjaan. Pengawasan hendaknya tidak hanya bertumpu kepada pimpinan tetapi juga diselenggarakan oleh semua anggota organisasi mulai dari manajemen puncak hingga manajer bawah yang secara langsung mengendalikan kegiatan-kegiatn teknis yang diselenggarakan oleh semua petugas operasional (Sondang 2007:125). Hani (2000:366) juga menyatakan bahwa sistem pengawasan memungkinkan manajer mendeteksi kesalahan-kesalahan sebelum menjadi kritis. Hal ini menunjukkan pentingnya pengawasan karena kebanyakan anggota organisasi sering membuat kesalahan-kesalahan.

\section{PENUTUP}

\section{Kesimpulan}

Berdasarkan hasil penelitian, maka dapt diambil kesimpulan sebagai berikut:

1. Terdapat hubungan yang berarti antara jam kerja, tata ruang kantor dan pengawasan dengan produktivitas kerja pegawai Badan Pemberdayaan Masyarakat Kabupaten Solok. Hal ini berarti semakin baik cara jam kerja, tata ruang kantor dan pengawasan maka produktivitas kerja yang akan diperoleh juga akan meningkat.

2. Terdapat hubungan yang berarti antara jam dengan produktivitas kerja pegawai Badan Pemberdayaan Masyarakat Kabupaten Solok. Hal ini berarti semakin optimal pemanfaatan jam kerja maka akan semakin baik pula produktivitas kerja pegawai.

3. Terdapat hubungan yang berarti antara tata ruang kantor dengan produktivitas kerja pegawai Badan Pemberdayaan Masyarakat Kabupaten Solok. Hal ini berarti semakin baik tata ruang kantor maka akan semakin baik pula produktivitas kerja pegawai.

4. Terdapat hubungan yang berarti antara pengawasan dengan produktivitas kerja pegawai Badan Pemberdayaan Masyarakat Kabupaten Solok. Hal ini berarti semakin baik pengawasan yang dilakukan maka akan semakin baik pula produktivitas kerja pegawai.

\section{Saran}


Dengan melihat hasil analisis dari penelitian ini, maka ada beberapa saran yang penulis ajukan, yaitu:

1. Bagi pegawai disarankan agar lebih meningkatkan kuantitas pekerjaan yang dapat diselesaikan dan pegawai dapat bekerja sesuai dengan jumlah jam kerja yang ada dan dimanfaatkan dengan baik untuk menyelesaikan pekerjaan.

2. Bagi pimpinan disarankan dapat memberikan dorongan agar pegawai lebih produktif dalam bekerja dan agar pimpinan bisa memberikan perhatian yang lebih terhadap pengawasan yang dilakukan khususnya untuk tindakan koreksi terhadap berbagai kesalahan atau penyimpangan yang mungkin dapat terjadi selama proses pekerjaan berlangsung.

3. Bagi kantor penulis menyarankan agar penataan ruangan kantor lebih diperhatikan baik bagi pimpinan dan pegawai sehingga dapat menciptakan suasana kerja yang baik dan nyaman terutama untuk penggunaan segenap ruangan agar komposisi ruangan menjadi lebih seimbang.

\section{DAFTAR PUSTAKA}

10.22202/economica.2015.v4.i1.262

Badri Munir Sukoco. (2006). Manajemen Administrasi Perkantoran Modern. Jakarta: Erlangga.

Faustino Cardoso Gomes. (2003). Manajemen Sumber Daya
Manusia. Yogyakarta: Penerbit Andi.

Henry Simamora. (2004). Manajemen Sumber Daya Manusia. Yogyakarta : STIE YKPN.

Ibnu Syamsi. (2004). Efisiensi, Sistem dan Prosedur Kerja. Jakarta: Bumi Aksara.

MC Maryati. (2007). Manajemen Perkantoran Efektif. Yogyakarta: UPP STIM YKPN.

Muchdarsyah Sinungan. (2008).

Produktivitas Apa dan Bagaimana. Jakarta: Bumi Aksara

Pandji Anoraga (2004). Manajemen Bisnis. Jakarta: Rineka Cipta.

Payaman J. Simanjuntak. (1998). Pengantar Ekonomi Sumber Daya Manusia. Jakarta: Lembaga Penerbit Fakultas Ekonomi Universitas Indonesia.

Petra. (2010). Tinjauan Pustaka: Jam Kerja dan Pengukuran Kerja. (http:www.digilib.petra.ac.id diakses 2 Maret 2012).

Slamet Saksono. (2001). Administrasi Kepegawaian. Yogyakarta: Kanisius

Sondang Siagian. (2002). Kiat Meningkatkan Produktivitas Kerja. Jakarta: Rhineka Cipta.

Hani Handoko. (2000). Manajemen Edisi 2. Yogyakarta: BPFE.

The Liang Gie. (2000). Administrasi Perkantoran Modern. Yogyakarta: Liberty. 